Copyright (C) 2014 by Academic Publishing House Researcher

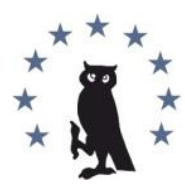

Published in the Russian Federation

European Researcher

Has been issued since 2010.

ISSN 2219-8229

E-ISSN 2224-0136

Vol. 86, No. 11-1, pp. 1964-1969, 2014

DOI: 10.13187/er.2014.86.1964

www.erjournal.ru

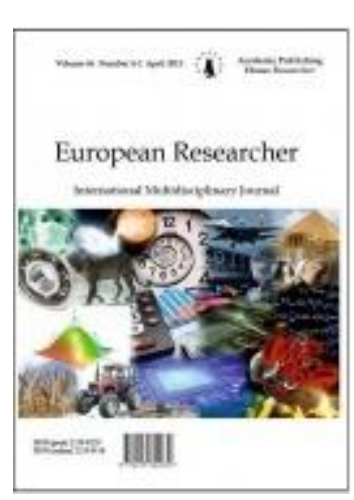

UDC 37.026:159.923

\title{
Modern Aspects of Schoolchildren's Creative Thinking Development
}

\author{
${ }^{1}$ Zhanar E. Sarsekeeva \\ ${ }^{2}$ Ekaterina F. Bogdanova
}

\begin{abstract}
${ }^{1}$ Karaganda State University of E.A. Buketov, Kazakhstan 100026, Kazakhstan, Karaganda, Universitetskaya St., 28 Doctor of pedagogical sciences, Associate professor

E-mail: sarsekeeva.04@mail.ru

${ }^{2}$ Karaganda State University of E.A.Buketov, Kazakhstan 100026, Kazakhstan, Karaganda, Universitetskaya St., 28

E-mail: bogdanova_ef@mail.ru
\end{abstract}

\begin{abstract}
This article is about actual problems of schoolchildren's creative thinking development. The changes happening in our society show absolutely different requirements to the younger generation than they were before which will become not only an active component of the state, but also the leading force in its further development in the closest future. Pedagogy of ideological dogmas, reproductive training, compounding and regulation of teacher and pupils' activity corresponded to the society of totalitarian consciousness, priority of a political and ideological orientation in full measure. Nowadays pedagogical technologies differ in the rigid organization of school life, suppression of pupils' initiative and independence, application of requirements and coercions. The personal focused technologies which gained new development at present moment are characterized by anthropocentricity, humanistic and psychotherapeutic orientation. They are aimed at versatile, free and creative development of the child. Only such active, creative personality is capable to realize in difficult social relationship of modern society. From the carried-out analysis of psychology and pedagogical literature it is possible to note that schoolchildren's creative thinking development is becoming the priority direction.
\end{abstract}

Keywords: creativity; creative thinking; children of younger school age.

\section{Введение}

Одной из основных проблем, стоящих сегодня перед системой образования и общества в целом, является проблема активизации творческого мышления младших школьников. Психологи утверждают, что развивать творческое начало в детях следует как можно раньше, в противном случае оно может угаснуть. Следовательно, необходима целенаправленная работа по развитию творческого мышления младших школьников с учетом возрастных и индивидуальных особенностей [1].

Анализ психолого-педагогической литературы (П.П. Блонский, Д.Б. Богоявленская, Л.С. Выготский, П.Я. Гальперин, В.В. Давыдов, А.Н. Леонтьев, Н.С. Лейтес, А.Н. Лук, Я.А. Пономарев. А.З. Рахимов, С.Л. Рубинштейн, Д.Б. Эльконин) позволяет определить 
творчество как процесс перманентного совершенствования своей личности, мышления, сознания, интеллекта; постоянного стремления создавать нечто новое, делать больше и лучше, чем прежде. Вопросами развития творческого мышления учащихся занимались также следующие ученые: Г. Найнер, В. Калвейт, Ж. Клейн, А.Э. Симоновский, В.С. Шубинский, Ю.Б. Гатанов, А. Матейко, А. Рошка, М.В. Клишина.

Творчество - это деятельность, порождающая нечто качественно новое и отличающаяся неповторимостью, оригинальностью и культурно-исторической уникальностью [2].

В связи с чем, мы полагаем, возникает необходимость рассмотрения именно особенностей проявления любознательности во взаимосвязи с творческими способностями личности, развитием творческого мышления.

\section{Цель исследования}

Целью статьи является исследование современных аспектов развития творческого мышления младших школьников.

\section{Материалы и методы исследования}

В качестве предмета исследования выступает изучение современных аспектов развития творческого мышления младших школьников. Основным методом исследования выступил теоретический анализ научной литературы, в частности, труды психологов и педагогов. В то же время в процессе исследования применялись такие логические методы, как анализ, синтез, обобщение и системный метод.

\section{Обсуждение}

Для эффективного развития творческого мышления учащихся в первую очередь необходимо обеспечить информационную базу деятельности, основой которой являются знания. Их эффективное усвоение зависит от многих факторов. Одним из важнейших является представление учебного материала в такой форме, которая наиболее соответствует особенностям восприятия и переработки информации учащимися, обладающими различными способами познавательной деятельности. Традиционно сложившее обучение базируется на развитии репродуктивного мышления и направлено преимущественно на содержание и объем получаемых знаний, а не на формирование средств и способов мыслительной деятельности [3].

В.Г. Рындак отмечает, что учитель сегодня в большой степени заинтересован в обогащении знаний по предмету, учащихся сориентированы на получение знаний «в готовом виде». Обеспечение же индивидуальной познавательной исследовательской деятельности учащихся позволяет активно осваивать не только предметную область знаний, но и развивать творческий потенциал [4].

Развитие творческого мышления и творческой деятельности необходимо осуществлять с учетом психолого-возрастных особенностей детей, а также методов и средств творческого развития, соответствующих этому возрасту учащихся.

У учащихся младшего школьного возраста происходят важные процессы развития всех сторон личности, в этом возрасте могут быть развиты стимулы творческого мышления и творческой деятельности. Начало творческого мышления и творческой деятельности начинается там, где учащиеся находятся в положении, которое дает возможность организовать свои действия начиная с идеи. При этом возникает новый тип деятельности, который может быть охарактеризован как переход к творческой деятельности. Мышление и деятельность вступают в отношения, делающие возможным переход от мысли к ситуации, а не от ситуации к мысли. Деятельность педагога в этом случае должна быть направлена на привлечение внимания учащихся к полученному результату, их поддержку, помощь в осмыслении созданного, побуждение к дальнейшей деятельности [5].

Образование в начальной школе является базой, фундаментом всего последующего обучения. В первую очередь, это касается сформированности общих учебных умений, навыков и способов деятельности, на которых лежит существенная доля ответственности за успешность обучения в основной школе. Уровень их развития определяет характер познавательной деятельности школьника, его возможности целесообразно и 
целенаправленно ее организовывать, владеть речевой деятельностью и способами работы с информацией и т.п. [5].

Опираясь на природную детскую любознательность, потребность самостоятельного познания окружающего мира, познавательную активность и инициативность, в начальной школе создается образовательная среда, стимулирующая активные формы познания: наблюдение, опыты, обсуждение разных мнений, предположений, учебный диалог и пр. Младшему школьнику должны быть предоставлены условия для развития способности оценивать свои мысли и действия как бы «со стороны», соотносить результат деятельности с поставленной целью, определять свое знание и незнание. Эта способность к рефлексии важнейшее качество, определяющее социальную роль ребенка как ученика, школьника [6].

Анализ психолого-педагогической литературы показал, что существуют различные точки зрения по определению понятия «творческое мышление».

Творческое мышление - познание чего-то нового. Оно является составной частью человеческого интеллекта. Такие навыки обеспечивают выживание человечества, a, следовательно, культурный континуум (цивилизацию) и развитие. Слово «новое» присутствует явно или подразумевается в большинстве случаев определений творчества. Каждый индивидуум имеет свой потенциал создания новых идей, отношений и объектов во всем множестве альтернатив, предоставляемых жизнью [7]. Творческое мышление - это мышление, основанное на воображении. Оно создает новые идеи, новый взгляд на вещи. Оно связывает определенные предметы или образы так, как их раньше не связывали. Оно бесконечно и разнообразно [8]. Творческое мышление - процесс создания чего-то нового, представляющего интерес для индивидуумов, группы, организации или общества [9]. Творческое мышление - способность взглянуть на проблему со стороны. Творческая мысль это проницательность, прозрение, миг вдохновения, который открывает верное решение [10]. Творческое мышление - результат взаимодействия ума и стимулов окружающего мира [11]. Творческое мышление - умение взглянуть на мир способом, отличным от того, как на мир смотрят другие. Умение выразить и передать этим другим свое восприятие окружающего мира [12]. Творческое мышление - существенный компонент, способствующий преобразованию и прогрессу [13]. Творческое мышление - способность находить принципиально новые, уникальные решения. Иногда творческое решение является результатом давно известных фактов в новую схему, а иногда представляет собой совершенно новую мысль, которая до этого момента никому не приходила в голову [14]. Я.А. Пономарев считает, что творческое мышление - это нейтральное психологическое звено творческой деятельности (процесса творчества) [15]. А. Рошка под творческим мышлением подразумевает такую форму мышления, которая составляет часть процесса творчества, результаты которого отличаются оригинальностью и социальной значимостью [16].

Таким образом, творческое мышление - один из интереснейших феноменов, выделяющих человека из мира животных.

Творческое письменное выражение мысли - один из видов речемыслительной деятельности человека, в которой проявляется высшая степень речевой активности. Творческие письменные работы оживляют уроки, увлекают самих учеников мыслеречевой деятельностью, нередко вносят элемент соревнования. Наиболее эффективным методом включения учеников в творческую деятельность на уроке является самостоятельная работа учащихся, направленная на выполнение различных текстовых упражнений под руководством учителя, но без его непосредственного участия. При этом методе работы учитель ставит вопросы, направляет деятельность учащихся, предполагает исходный материал, на основе которого школьники создают творческую работу. Учащиеся анализируют материал, формулируют задание, с учетом которого выполняют упражнение, самостоятельно контролируют и оценивают работу [17].

При этом в начальной школе следует использовать различные виды творческих письменных упражнений: «Создание двух текстов из одного псевдотекста по смыслу», «Создание двух текстов из одного, содержащего слова-омонимы», «Создание текста учащимися по кругу», «Создание текста-загадки по кругу», «Придумай сказку» и т.д. Творческие письменные упражнения повышают активность, самостоятельность учащихся и способствовали развитию мыслительных операций (анализ, синтез, нахождение сходств и различий, обобщение и систематизация, объяснение и доказательство) за счет 
систематического использования антиципации (предопределения, предвосхищения учащимися содержания, видов и результатов предстоящей учебной деятельности): целенаправленного и интенсивного развития творческого мышления. При выполнении творческих письменных упражнений, учащиеся творчески, самостоятельно подошли к выполнению заданий: распространили предложения, дополнили тексты интересной, познавательного характера информацией, придумали простые, сложные, разные по эмоциональной окраске предположения.

\section{Результаты}

Источником творческой деятельности является общественная необходимость в том или ином новом продукте. Именно потребность общества в чем-то обуславливает возникновение творческой идеи, творческого замысла, что ведет к созданию нового. Вся деятельность человека в состоянии вдохновения сосредоточена на предмете творчества. Вдохновение нельзя противопоставлять труду, оно есть результат большого труда.

Чтобы получить доброкачественный материал для творческой деятельности, человеку необходима высокоразвитая наблюдательность. Умение целенаправленно и тонко наблюдать - одна из характерных черт людей, создающих новое в той или иной области человеческой деятельности. Большие запасы наблюдений создают богатый материал для деятельности творческого воображения. Наблюдение дает возможность увидеть не только то, что нужно для осуществления наличного замысла, но и то, что дает толчок к постановке новых проблем, к возникновению новой идеи, нового замысла. Возможно, будет разумным полагать, что творить, способен всякий, но вот степень творчества меняется в очень широких пределах.

Творчество живет в большей или меньшей степени в каждом ребенке. Увидеть любое творческое проявление ученика, создать для развития творческих способностей на уроках и во внеклассной работе - эти задачи, на наш взгляд, должен ставить перед собой каждый учитель начальных классов [18].

\section{Заключение}

На современном этапе развития общества, происходящие изменения в социальной, экономической и политической сферах оказывают влияние на систему образования в целом и на ее модернизацию в частности.

Изменяющееся общество предъявляет к человеку совершенно иные требования, в отличие от прошлых лет. При этом основной задачей образовательных реформ является всестороннее развитие личности, способной не только умело ориентироваться в информационном пространстве, но и активно, творчески преобразовывать окружающую действительность. Интенсивное внедрение развивающих программ в образовательное пространство способствует активизации познавательной деятельности учащихся, тем самым, предъявляя повышенные требования к реализации творческого мышления. Однако, несмотря на масштабность и разноплановость исследований, касающихся различных свойств личности, проблема развития и проявления любознательности на данный момент остается недостаточно изученной.

Творчество и творческая деятельность определяют ценность человека, поэтому формирование творческой личности приобретает не только теоретический, но и практический смысл. Эффективность работы учителя подтверждается тем, в какой мере учебно-воспитательный процесс обеспечивает развитие творческих способностей ученика, формирует творческую личность и готовит ее к познавательной активной деятельности.

\section{Примечания}

1. Бушуева Л.С. Методы активизации творческого мышления младших школьников // Начальная школа. 2008. № 3. С. 13-16.

2. Ушачев В.П. Творчество в системе образования. М., 1995.

3. Афонина Р.Н. Развитие творческого мышления учащихся в процессе выполнения экспериментов // Начальная школа. 2007. № 6. С. 56-60.

4. Рындак В.Г., Московина А.В. Личность. Творчество. Развитие. М., 2002. 
5. Махмутов М.И. Развитие познавательной активности и самостоятельности учащихся в школах Татарии. Казань: Таткнигиздат, 1983. 80 с.

6. Подласый И.П. Педагогика. М.: Гуманит. изд. центр ВЛАДОС, 200о. Кн. 2. 256 с.

7. Ниренберг Дж. И. Искусство творческого мышления. Минск: Попурри, 1996. 236 с. $162 \mathrm{c}$.

8. Клишина М.В. Проблемы формирования творческого мышления. Караганда, 1999.

9. Ковалев А.Г. Психология личности. М.: Педагогика, 1980. 391 с.

10. Крылов Е. Школа творческой личности. М., 1992.

11. Березина В.Г., Викентьев И.Л., Модестов С.Ю. Детство творческой личности. СПб.: Издательство Буковского, 1994.

12. Левин В.А. Воспитание творчества. Томск: Пеленг, 1993.

13. Смирнов В.А., Смирнова И.М. Активизация деятельности учащихся. М.: Просвещение, 1992. 325 с.

14. Шардаков М.Н. Очерки психологии школьника. М.: Знание, 1995. 339 с.

15. Пономарев Я.А. Психология творчества и педагогика. М., 1989.

16. Рошка А. Творческое мышление. Пути его определения и развития. М.: Наука, 1987.

17. Смирнова О.И. Виды творческих письменных работ на уроках русского языка // Начальная школа. 2009. № 1. С. 42-46.

18. Клевцова Л.Е. Развитие способностей школьников // Начальная школа. 2009. № 10. C. $80-82$.

\section{References:}

1. Bushueva L.S. Metody aktivizacii tvorcheskogo myshlenija mladshih shkol'nikov // Nachal'naja shkola. 2008. № 3. S. 13-16.

2. Ushachev V.P. Tvorchestvo v sisteme obrazovanija. M., 1995.

3. Afonina R.N. Razvitie tvorcheskogo myshlenija uchashhihsja v processe vypolnenija jeksperimentov // Nachal'naja shkola. 2007. № 6. S. 56-60.

4. Ryndak V.G., Moskovina A.V. Lichnost'. Tvorchestvo. Razvitie. M., 2002.

5. Mahmutov M.I. Razvitie poznavatel'noj aktivnosti i samostojatel'nosti uchashhihsja v shkolah Tatarii. Kazan': Tatknigizdat, 1983. 80 s.

6. Podlasyj I.P. Pedagogika. M.: Gumanit. izd. centr VLADOS, 2000. Kn. 2. 256 s.

7. Nirenberg Dzh. I. Iskusstvo tvorcheskogo myshlenija. Minsk: Popurri, 1996. $236 \mathrm{~s}$.

8. Klishina M.V. Problemy formirovanija tvorcheskogo myshlenija. Karaganda, 1999. $162 \mathrm{s.}$

9. Kovalev A.G. Psihologija lichnosti. M.: Pedagogika, 1980. 391 s.

10. Krylov E. Shkola tvorcheskoj lichnosti. M., 1992.

11. Berezina V.G., Vikent'ev I.L., Modestov S.Ju. Detstvo tvorcheskoj lichnosti. SPb.: Izdatel'stvo Bukovskogo, 1994.

12. Levin V.A. Vospitanie tvorchestva. Tomsk: Peleng, 1993.

13. Smirnov V.A., Smirnova I.M. Aktivizacija dejatel'nosti uchashhihsja. M.: Prosveshhenie, 1992. $325 \mathrm{~s}$.

14. Shardakov M.N. Ocherki psihologii shkol'nika. M.: Znanie, 1995. 339 s.

15. Ponomarev Ja.A. Psihologija tvorchestva i pedagogika. M., 1989.

16. Roshka A. Tvorcheskoe myshlenie. Puti ego opredelenija i razvitija. M.: Nauka, 1987.

17. Smirnova O.I. Vidy tvorcheskih pis'mennyh rabot na urokah russkogo jazyka // Nachal'naja shkola. 2009. № 1. S. 42-46.

18. Klevcova L.E. Razvitie sposobnostej shkol'nikov // Nachal'naja shkola. 2009. № 10. S. 80-82. 
УДК 37.026:159.923

\title{
Современные аспекты развития творческого мышления младших школьников
}

\author{
${ }^{1}$ Жанар Есентаевна Сарсекеева \\ ${ }^{2}$ Екатерина Фаридовна Богданова
}

${ }^{1}$ Карагандинский государственный университет им. Е.А. Букетова, Казахстан 100026, Казахстан, г. Караганда, ул. Университетская, 28

Доктор педагогических наук, доцент

E-mail: sarsekeeva.o4@mail.ru

${ }^{2}$ Карагандинский государственный университет им. Е.А. Букетова, Казахстан

100026, Казахстан, г. Караганда, ул. Университетская, 28

Магистрант

E-mail: bogdanova_ef@mail.ru

Аннотация. В статье рассматриваются актуальные проблемы развития творческого мышления младших школьников. Изменения, происходящие в нашем обществе, предъявляют совсем иные, нежели ранее требования к подрастающему поколению, которое в недалеком будущем станет не только активным компонентом государства, но и ведущей силой в его дальнейшем развитии. Обществу тоталитарного сознания, приоритетности политической и идеологической направленности в полной мере соответствовала педагогика идейных догм, репродуктивного обучения, рецептуры и регламентации деятельности учителя и учеников. Педагогические технологии этого времени отличаются жесткой организацией школьной жизни, подавлением инициативы и самостоятельности учащихся, применением требований и принуждения. Личностно-ориентированные технологии, получившие новое развитие в наше время, характеризуются антропоцентричностью, гуманистической и психотерапевтической направленностью и имеют целью разностороннее, свободное и творческое развитие ребенка. Только такая, активная, творческая, личность способна реализовать себя в непростых социальных взаимоотношениях современного общества. Из проведенного анализа психолого-педагогической литературы можно констатировать, что развитие творческого мышления младших школьников становится приоритетным направлением.

Ключевые слова: творчество; творческое мышление; дети младшего школьного возраста. 